\title{
A Strategic Conceptualization Of The IT Outsourcing Decision And The Role Of Teams
}

Terry R. Adler, (Email: tadler@nmsu.edu), New Mexico State University Robert F. Scherer, (Email: r.scherer@ csuohio.edu), Cleveland State University Janice A. Black, (Email: janblack@nmsu.edu), New Mexico State University

\begin{abstract}
We examine how organizational, individual, and team factors affect team-based judgment of value for outsourcing information technology (IT) services. The study of team-based judgment of value is important because team designs are growing in popularity to support the customization of IT services to meet larger, organizational objectives. A strategic reconceptualization of how IT outsourcing decisions are operationalized through team-based judgments of value is fundamental for understanding how organizational objectives, work requirements, and contractual conditions are framed and executed.
\end{abstract}

\section{Introduction}

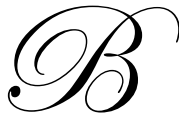

ecause there is interdependence among information technology (IT) tasks, the study of team-based designs naturally involves a closer look at the role of social context and discourse communities. Colomb and Williams (1985) define the concept of a discourse community as a singular discipline, conceived to bring about a specific end-result beyond the experience of the particular community, as typically generated within such professions as law, business, medicine, and academics. In general, any future study of teams requires a study of context because teams are embedded in larger social systems (Cohen \& Bailey, 1997). Teambased writing of IT outsourcing requirements represents a forum where conflicting discourse norms converge because collective team values are affected through social discourse.

Many scholars and practitioners need to rethink how team judgment of value is affected in team-based designs. This is especially true when teams evaluate IT providers to implement organizational outsourcing decisions (Lacity, Willcocks, \& Feeny, 1996; Venkatraman, 1997). While individual values lead to certain behaviors, we argue that membership in team-based designs leads to unique and persistent team values that support, complement, or contrast with individual or organizational decisions to outsource. For instance, teams may collaborate and lend valuable resources to other teams in supporting superordinate, organizational goals, while other teams may exhibit unnecessary, prolonged self-survival values and behavior that conflict with organizational objectives (Adler, 2000).

The purpose of the current discussion is to provide a strategic framework for understanding how teambased judgments of value are formed and affected by different discourse communities made up of organizational, team, and individual processes and factors that ultimately affect team decisions and outcomes. We provide this analysis under the rubric of outsourcing IT services because outsourcing IT work frequently deals with important organizational changes in novel environments with regard to how IT fills organizational gaps or needs (Grover, Cheon, \& Teng, 1994; Sengupta \& Zviran, 1997). Previous research has demonstrated that novel environments, like the outsourcing of IT services, are important for studying intra-team adaptation and communication processes based on how team mental models are shared between team members (Coovert, Craiger, \& Cannon-Bowers, 1996; Marks, Zaccaro, \& Mathieu, 2000). We suggest that team judgment of value is a precursor to shared mental models and

Readers with comments or questions are encouraged to contact the authors via email. 
decision-making within teams. While novel environments are an excellent venue for studying team-based judgments of value, we believe the study of an IT outsourcing effort also provides an ideal situation to study team-based effects. Since team-based designs are commonly used to accomplish IT work in organizations (Gordon, 1992; Offerman, 2001), the study of IT outsourcing provides a rich context to study how team judgment of value becomes salient and linked with other team processes, providing a basis for further research on how team judgment of value affects team decision-making and outcomes.

\section{Team-Based Judgment of Value}

We propose that team-based judgment of value is closely linked to the shared mental models literature. Shared mental models are defined as the content and organization of team-interaction knowledge held by team members within a performance setting (Marks et al., 2000). The study of shared mental models is in its infancy as demonstrated by the fact that researchers have used many different names to describe shared mental models like team-member schema agreement, cognitive consensus, transactive memory, information sharing, group learning, and collective mind and cognition (Gibson, 2001; Mohammed \& Dumville, 2001; Rentsch \& Klimoski, 2001; Wegner, 1986; Weick \& Roberts, 1993).

We believe the inconsistent definition of team shared mental model constructs indicates that the study of the relationship between team processes, shared mental models, and outcomes needs further study. We suggest that team mental models are affected by how teams perceive and judge the value of team-based assignments in the development of shared mental models. Thus, while team-shared mental models focus on collective knowledge, the effect of collective beliefs or values also must be considered. A team-based judgment of value is defined as a shared, strongly-held expectation, or set of expectations, that guides team member behavior in the performance of team objectives in an organizational setting. For example, trust and distrust are expectations formed from the interaction of team members with the team's environment (Martell, Guzzo, \& Willis, 1995; Zand, 1972). A team-based judgment of value is different from group norms which are defined as informal rules that groups adopt to regulate behavior (Feldman, 1984). A judgment of value is much less constraining than a group norm since a norm is a criterion or standard of performance. A judgment of value rests merely in the team's collective view of others and themselves as a basis of team interaction.

Culture can also play a part in the transference of institutional expectations to team expectations (Schein, 1983). Teams can experience trust and distrust with other individuals, teams, and organizations and retain this belief in the collective setting of the team. Since values can be unique from team to team, there should be just as much variance between team-based judgments of value as there is between human judgments of value (Rokeach, 1973).

Teams are defined as "a distinguishable set of two or more people who interact, dynamically, interdependently, and adaptively toward a common and valued goal, objective, or mission, who have each been assigned specific roles or functions to perform" (Salas, Dickinson, Converse, \& Tannenbaum, 1992). Team-based judgments of value guide team member actions by focusing on team issues within the larger organizational setting. The nature of team membership places an onus on team members to judge what are acceptable standards of behavior with regard to achieving consensus of team objectives and outcomes. This leads us to the study of factors that influence teambased judgments of value.

\section{A Social Perspective in Team-Based Designs}

In our review of the outsourcing literature, we found that teams play a critical role in outsourcing IT work because these efforts typically have organizational implications (e.g., strategic ties; Ang \& Straub, 1998; Lacity et al., 1996). Team-based designs make the development and communication of outsource requirements an extremely difficult task because of social effects that frequently require the integration of norms, organizational actions, and IT infrastructure (Bazerman, 1983; Knorr \& Knorr, 1978; Lacity \& Willcocks, 1998; Niederman, Brangeay, \& Wetherbe, 1991). 
An IT infrastructure is defined as the complex set of IT resources that provide a technological foundation for firms' present and future business applications (Earl, 1989; Lacity \& Willcocks, 1998; Niederman et al., 1991; Venkatraman, 1997). This infrastructure usually includes platform hardware and software, network and telecommunications technology, core organizational data, and data processing applications that are fundamental to the organization. An IT outsourcing effort, thus, represents a team's best guess at what fundamental IT requirements are necessary to meet future business applications and gaps (Grover et al., 1994). The study of team-based judgment of value in an IT outsourcing venue should provide insight into how team-based judgments of value develop when faced with an important organizational implementation.

\section{Outsourcing IT Services as a Bundle of Interests}

The primary reasons organizations outsource IT services vary widely from managerial flexibility to anticipated cost savings (Ang \& Straub, 1998; Currid, 1994; Duncan, 1995; Hopper, 1990; MacMillan, 1997; Outsourcing Institute, 1996; Remenyi, 1996; Richmond \& Seidmann, 1993). This requires a multi-level study of outsourcing IT services since organizational, team, and individual activities are affected by IT outsource decisions. Outsourcing is defined as the significant contribution by extra-organizational service providers of the physical and human resources associated with the entire, or components of, the IT infrastructure (Loh \& Venkatraman, 1992). Team-based perceptions of the value of the IT services outsourced is dependent on many factors. We present a robust set of organizational, individual, and team factors pertinent to the development of team-based judgments of value in an IT outsourcing framework (see Figure 1).

Given that the introduction of new IT providers frequently causes social change in organizations, effective IT implementation depends upon factors that influence the team implementation process. As diagrammed in Figure 1 , we propose that organizational processes, individual knowledge sharing and discourse norms, power issues, and the emergent perspective, be considered in their affects on a team-based judgment of value with regard to IT outsource decisions and implementation. While organizations decide to outsource more frequently, teams often carry the responsibility for implementing these decisions in vendor selection and administration. The factors in Figure 1 are salient to team-based judgments of value because IT services will be developed and provided by extraorganizational providers, thus, creating novel environments in the allocation of IT resources between organizational members (Lacity et al., 1996). Skinner and Bond (1997) add that outsourcing of IT work considers what is core to a company in deciding what a firm should and should not do. Therefore, teams charged with deciding the details on the outsourcing of IT services are in reality fulfilling a larger organizational and strategic objective in the "make or buy" decision. The strategic implementation of IT outsourcing decisions is left to the IT outsourcing team in framing lower-level objectives, work requirements, and contractual conditions. Thus, team-based designs support the customization of IT services to meet larger, organizational objectives (Grover \& Ramanlal, 1999).

\section{Model of Factors}

Since the outsourcing of IT services hinges on the conveyance of expectations, teams must communicate project requirements to the IT supplier, normally in contractual form. Team-based judgments of value influence how IT project requirements are written. For instance, IT requirements can be written fairly open-ended to allow the IT provider flexibility in providing system support or requirements can be written narrowly to provide a service at a certain time with the agenda controlled by the organization (Lacity et al., 1996; Lacity \& Willcocks, 1998). The process of writing requirements, as evidenced in the writing of technical requirements literature, is complex and dependent on general socialization processes (Adler, 2000; Bazerman, 1983; Dannels, 2000; Odell \& Goswami, 1985; Scarbrough, 1995). Given the complexity and pace of change of IT in the firm, incorporating a team-based judgment of value into the IT outsourcing decision framework is not only necessary but fundamental to evaluating follow-on IT outsourcing performance and team-based outcomes. 
Figure 1 Model of Factors and Processes Affecting Team Member Judgments of IT Outsourcing Value

\section{Organizational Processes}

P1: Signals of support for IT outsourcing effort $(+)$

P2: Strategic impact of outsourcing on organizational objectives (+)

P3: Development/communication of clear objectives (+)

Shared Knowledge \& Discourse Norms in Team-Based Designs

P4: Perception that non-technical team members improve the knowledge-sharing process $(+)$

P5: Perception that requirements are diluted (-)

\section{Power Issues \& Linear Writing Practices}

P6: Power influences in writing outsourced requirements (-)

P7: Extent of linear writing practices (-)

\section{Emergent Perspective}

P8: Agreement that IT contract developers viewed as mediators not translators $(+)$

$\mathbf{P 8}_{\mathbf{b}}$ : Agreement that outsourced work provides an opportunity to internal members (+)

P8 $_{c}$ : Agreement that IT expertise resides external to the firm (+) 
Below we discuss the linkages (see Figure 1) that lead to a team-based judgment of value for the outsourcing of IT work. We shall consider key organizational processes that affect team commitment, individual knowledge sharing, discourse norms in team-based designs, and the emergent perspective.

\section{Organizational Processes That Escalate Commitment}

Teams are embedded in the larger social context of organizational processes and factors. For instance, Cohen and Bailey (1997) discuss how organizational context like rewards and supervision affect internal team processes and effectiveness. We discuss the effects of three related organizational processes on team-based designs in the context of outsourcing IT work: signals of support from management, the strategic impact of outsourcing on organizational operations, and the development and communication of clear organizational goals.

\subsection{Signals of Support From Management}

Bishop, Scott, and Burroughs (2000) describe how perceived team support is strongly related to team commitment. Signals of support from top management affect the successful outsourcing of IT services as these signals send important messages to team members about the vision, worth, and value of the outsourcing effort (Forbes, 1998; Weill \& Broadbent, 1998). Lacity et al. (1996) describe how senior management needs to be involved in inviting external and internal bids for IT outsource teams to consider. The active involvement of senior management sends important signals of support to teams involved in the ultimate implementation of senior management decisions. Researchers have empirically investigated how lower-level managers have interpreted the importance of strategic vision communicated by top-level management. The results have been summarized into three broad areas: issue definition and labeling, an assessment of the effects of the issue, and an analysis of an organization's response to an issue.

The discussion of these areas in team-based designs leads many individuals to change their perception of value as new information is provided. Westley and Mintzberg (1989) suggest that one of top-level management's challenges is setting a vision that that can be implemented by teams in the performance of organizational objectives. Some issues are routine and simplistic and teams can more easily recognize and implement them with a well-learned response (Starbuck \& Milliken, 1988). For non-routine issues, management's framing of the issue is key to how teams interpret appropriate responses, especially in determining the value of a complex and interdependent effort (Dutton \& Dukerich, 1991).

The implementation of IT outsourcing services is similarly complex and interdependent. In organizations where IT is strategically mapped to critical business processes, and skills are available internally, even the mention of outsourcing is quite controversial. Teams that get support from top management in implementing the strategic vision, albeit with negative consequences to some internal resources, will still positively view the IT outsourcing effort because team members will justify their behavior on the team. For instance, Keil (1995) found that individual commitment escalated in IT projects, even with negative feedback, due to an individual's justification of their behavior. The more team members justify their behavior, the more teams build consensus that further escalates commitment for the IT outsourcing effort (Woolridge \& Floyd, 1990). Thus, as signals of support from top-management are received by team members in implementing a firm's strategic vision, the stronger team commitment becomes in developing a consensus of strongly held team beliefs or team judgment of value.

Proposition 1: The more management sends signals of support for the IT outsourcing effort, the more team commitment escalates, and, consequently, the more likely team members will form a judgment of value of the IT outsourcing effort.

\subsection{Strategic Impact of Outsourcing}

An analysis of the outsourcing effort with regard to expected costs and benefits is rooted in the efficiency framework. Davy (1998) found that the primary reason firms outsource is that an outsourcing provider can assist a firm in reducing costs and improving efficiency (Williamson, 1983). Savings, or benefits, come from the economies 
of scale offered by outsourcing providers. With expected savings ranging from twenty to forty percent, the economic incentive to outsource is the primary justification for this activity (Ang \& Straub, 1998; Lacity \& Hirschheim, 1995). Savings typically come from the loosening up of both human resources and equipment for other purposes. Managers gain considerable strategic flexibility in tailoring newly available resources to fit their project needs in a timely manner (Currid, 1994; Hitt, Keats, \& DeMarie, 1998).

Team commitment should also escalate as team members realize that top management is saving money to satisfy superordinate organizational goals (Grover, Cheon \& Teng, 1994; Staw \& Fox, 1997). Team members are more likely to develop team commitment when meeting organizational goals than when meeting other team-based goals because of the diverse, and sometimes competing, nature of IT services. Lacity et al. (1996) suggests that IT be viewed as a portfolio of organizational tasks since many IT services are interdependent, complex, and farreaching. Given the choice of satisfying competing team and organizational tasks, team members will opt to commit to team tasks that best support the achievement of organizational objectives (Tyerman \& Spencer, 1983). Research on individual-organization linkages has explored the relationship between team commitment and organizational outcomes (Bishop \& Scott, 2000; Bishop et al., 2000). These studies have demonstrated that perceived task interdependence is highly related to team commitment. The outsourcing of IT services is a perfect environment for building team commitment when the team-based effort is tied to strategic intent of the organization (Grover et al., 1994). Team commitment to the IT outsourcing effort will also increase as team members perceive the advantages of outsourcing IT infrastructure to satisfy organizational goals and increase the potential achievement of organizational outcomes (Ang \& Cummings, 1997; Nam, Rajagopalan, Rao \& Chaudhury, 1996). Teams acting as proxies for strategic decision makers will develop team commitment and team-based judgments of value for the IT outsourcing effort the more the team's purpose is tied to organizational objectives.

Proposition 2: The more outsourcing is perceived by team members as tied to organizational objectives, the more team commitment escalates and, consequently, the more likely team members will form a judgment of value of the IT outsourcing effort.

\subsection{The Establishment and Communication of Clear Organizational Objectives}

The development of organizational objectives, therefore, is a strategic task of top-management and communicating these objectives clearly can lead to a competitive advantage for the firm (Latham \& Yukl, 1975). Some researchers posit that a labyrinth exists in organizations of lower-level goals and strategies developed by individuals and teams to meet top-management's objectives (Nicholson, 1996). However, the adequate communication of organizational objectives to teams to implement these objectives is fraught with risk.

Support for this hypothesis comes from the Outsourcing Institute's (1996) series of studies that found for outsourcing to be successful, management must have a clear set of goals in mind before the outsourcing decision is made. Given that teams are a primary way to fulfill organizational work (Katzenbach \& Smith, 1993; Salas et al., 1992), management must communicate goals clearly to IT outsourcing teams about meeting expectations and the fulfillment of strategic intent (DiRomualdo \& Gurbaxani, 1998; Fielden, 2001).

The establishment of clear objectives has also been shown to be moderately related to increasing team commitment (Hollenbeck, Williams, \& Klein, 1989). 'Clear' in this sense means the ability to communicate links between organizational and team goals that teams can then use to frame team purpose and work. Given the myriad of competing uses of IT infrastructure within organizations, clearly stated organizational objectives lead to a consensual set of strongly held beliefs, or judgments of value, within a team setting that is important for carrying out the outsourcing of IT work. The clear communication of organizational goals will lead to increased team member commitment because team members can identify with the organization's strategic purpose for the outsourcing effort (Lee \& Kim, 1999). The development of team commitment will also support the development of team-based judgments of value for the IT outsourcing effort.

Proposition 3: The more outsourcing is based on clearly stated objectives, the more team commitment escalates and, consequently, the more likely team members will form a judgment of value of the IT outsourcing effort. 
Knowledge sharing between individuals is essential for improving team effectiveness especially when different discourse communities are represented on a team (Dougherty, 1992; Gibson, 2001). In the context of IT outsourcing, we discuss the effects of two related perceptions in team-based designs with regard to sharing knowledge between discourse communities: the perception that non-technical team members improve the knowledge-sharing process and the perception that requirements are diluted.

\subsection{Improved Knowledge-Sharing and Discourse Norms}

Discourse communities affect the context under which individuals read and evaluate written requirements in team-based settings (Odell, Goswami, Herrington, \& Quick, 1983). Discourse communities develop norms for administering appropriate behavior of individuals as members of these discourse communities. Team-based designs integrate diverse discourse norms as they play out in the development of IT outsource contracts. Discourse norms frequently affect the process of contract development due to effects from individuals, groups, and organizations who have a vested interest in the uniqueness of the "terms and conditions" in the contract (Adler, 2000). Collective agreement on IT outsource requirements necessitates a sharing of information and beliefs about discourse communities through team members. For instance, Burnham (1986) provides four case studies in his Writing across the Curriculum course highlighting how professors from different discourse communities collaborate by sharing lessons learned from their unique writing experiences.

The goal of sharing lessons learned and knowledge between team members is to increase the effectiveness of team performance and, ultimately, organizational success from the IT outsourcing effort. Since an ability to learn is a source of sustainable competitive advantage for firms (Senge, 1990), Fielden (2001) suggests that organizations need to create an environment where knowledge is shared effectively, especially when planning an IT outsource effort. The more team members can share knowledge about the outsourcing effort, the more they will value the outsourcing effort with regard to meaningfulness of work, job satisfaction, participation, and productivity (Plunkett, 1990; Sashkin, 1984).

Unfortunately, not all team-based frameworks lead to knowledge sharing (Wheelwright \& Clark, 1992). Consequently, writing processes and products, like IT outsourcing agreements frequently become meaningless, as MacNeil (1978) has stated, with regard to enforcement and practicality. Contract writers have historically done a poor job of adequately communicating and integrating outsource requirements and control mechanisms to turn off outsource efforts (Adler, 2000; Hirschheim \& Lacity, 1998).

However, the diversity of team membership can be a positive factor in how teams work, especially when innovation is required in novel environments (Eisenhardt \& Tabrizi, 1995; Magjuka \& Baldwin, 1991). For instance, non-technical team members in an outsourcing effort can provide valuable information to support outsourcing requirements writing since they are not tied to a particular IT infrastructure. This is a similar situation to what Scarbrough (1995) calls a "hostage strategy" in using many occupations to communicate knowledge in organizing a contract transaction. Also, Selzer (1983) found that the more experience engineers obtain, the more they recognize the value of talking to others during the writing composition process. Team-based designs that incorporate the inputs of all team members, especially non-technical team members, and attempt to maximize knowledge-sharing between team members, will most likely develop stronger and collectively held team-based beliefs for the IT outsourcing effort.

Proposition 4: To the extent team members perceive that non-technical team members contribute to the knowledgesharing process in an IT outsourcing effort, the more likely team members will form a judgment of value of the IT outsourcing effort. 
Outsourcing of IT infrastructures certainly should consider other occupations and part-whole relationships to understand what is central to operations and support (Weill \& Broadbent, 1998). Unfortunately, developing contract, or technical, requirements is a difficult and complex process, different from broad-based, knowledge-sharing activities, and quite dependent on the social skills of the IT, or engineering, personnel in team-based designs (Odell et al., 1983; Dannels, 2000). Can IT technical members explain, integrate, and persuade non-technical IT and nonIT team and organizational members in the development of contract requirements? Research indicates that these skills are not adequately taught in our undergraduate curriculums (Anson, 1988; Dobrin, 1983).

The writing of IT contract requirements is a complex process especially when teams are faced with novel environments typically associated with IT outsource implementation (DiRomualdo \& Gurbaxani, 1998; Lacity et al., 1996; Venkatraman, 1997). Recent research indicates that detailed contract requirements are better than open-ended philosophies in the outsourcing of IT services (Lacity \& Willcocks, 1998). Since the outsourcing of IT is becoming more pronounced, top management correspondingly is more involved in the monitoring and support of IT outsource contracts (Duncan, 1995; Hitt et al., 1998). This continual review by top management, and the layers of review possibly by mid-hierarchy management, has led to a dilution of contract requirements necessary to adequately describe, explain, and control the IT outsource effort.

Adler (2000) found that dilution occurred when the technical aspects of requirements were changed, modified, and consequently diffused, from a team-based writing perspective, when requirements were coordinated with non-technical team members. Dilution happens when IT requirements become wordy and details are omitted, weakening the validity and meaning of the original requirement. In addition, Adler found that while many of the study participants felt that cross-functional teams added more diverse information in the decision making process, diverse opinions also weakened the technical descriptions, definitions, and conciseness of the requirements. Interestingly, when internal reviewers of written requirements had questions about the meaning of a requirement, the typical response was to change, or add, more definition.

Dilution is dangerous from a legal and productivity perspective. Contract requirements are interpreted as a whole when reasonably possible (Lamir, 1992). While teams may have "technical maturity" where they can adequately define contract requirements (Lacity et al., 1996), the multiple reviews of these requirements may weaken their meaning, thus, creating the dilution effect. When requirements are incomplete, useless, or ineffective, legal interpretation of a requirement will generally be rejected. When requirements become diffused, there is essentially no legal requirement between buyer and seller. Legitimate changes, from a legal perspective, generally are intended to ensure validity and completeness of requirements.

Since language derives its meaning largely from its context, an attempt to interpret a word or phrase independent of the overall requirement may distort its meaning and not reflect the intent of both parties. Descriptive and additional information added to requirements as a result of collective authorship may attempt to clarify professional jargon or the intent of the transaction. Dilution may also occur when uncommon words and concepts, without shared meaning, are deleted in order to facilitate the understanding of a broader audience. The practice of developing requirements in cross-functional teams exacerbates this problem because shared meaning of terms, conditions, and jargon may not exist. For instance, Trice (1993) referred to legal reviews as deal killers because of the dilution of the requirement's meaning. A legal review of technical requirements before the award of a contract, however, is necessary to avoid situations leading to post-interpretation ambiguities, especially when there is no consistent guidance (Lamir, 1992). Technical dilution occurs when IT team members have to change requirements, due to broader functional and organizational reviews, lessening the ability of a team to develop shared judgments of value of the IT outsourcing effort.

Proposition 5: To the extent that team members perceive that the process of reviewing IT outsourcing agreements dilutes contract requirements, the less likely team members will form a judgment of value of the IT outsourcing effort. 


\section{Power Issues and Linear Writing Practices}

Any study of teams as an intact social system made up of diverse discourse communities invariably involves competition and cooperation among its team members to get work done (Tyerman \& Spencer, 1983). The nature of outsourcing IT work is inherently competitive as organizations shift work, change internal work assignments, and integrate external resources. We discuss two important factors with regard to competition for scarce organizational resources: power influences and linear writing techniques.

\subsection{Power Influences}

Writing contract requirements is an important facet of team-based communication with regard to political and power agendas that are played out in the implementation of IT outsourcing decisions (Anson, 1988; Friedlander, 1993; Jolliffe \& Brier, 1988; Kramberg-Walker, 1993; Renze, 1996). Since writing is a socially constructed process (Couture \& Rymer, 1993), the effective development of technical requirements may be more dependent on how team members, especially those who typically own the IT requirements, perceive how their status and discourse community is affected by the IT outsource agreement.

The reasoning presented here also supports arguments made by Eisenhardt and Bourgeois (1988) that the greater the use of power in team-based designs the more emphasis is placed on self-interest seeking. Agency theory provides a model that suggests that outsource team members may sabotage IT outsource requirements to fulfill their own agendas from a moral hazard concern (Eisenhardt, 1989). This is one reason why Weill and Broadbent (1998) suggest that management not abdicate the IT outsourcing decision to technical managers.

Thus, the more team members perceive that power-based influences affect team decisions, the less likely teams will develop collectively held beliefs about an IT outsourcing effort because there will always be winners and losers in power-based struggles. Teams that struggle to balance self-interests with team interests will also struggle in developing consensual judgments of value that guide individual team member behavior.

Proposition 6: The more team members use power-based processes to influence the development of contract requirements, the less likely team members will form a judgment of value of the IT outsourcing effort.

\subsection{Linear Writing Practices in the IT Outsource Decision}

Many organizations use linear writing processes to develop IT outsource requirements that exacerbate an already difficult communication process between strategy-makers and teams (i.e., strategy-implementors). Linear writing processes are defined as the composition and integration of requirements in a sequential and incremental fashion (Reither, 1993). This means that requirements are typically developed by individuals first at a subsystem level and then integrated together in a team-based design (Dannels, 2000).

Linear writing processes occur in team-based designs when reading, writing, and then collaborating is done in rational sequence (Reither, 1993). While ideal possibly from an engineering perspective, this almost never happens because writing is typically collaborative and discursive, cycling back and forth between team members, dependent on the situation, or transaction, under consideration, prone to random input through collective thought.

Team-based designs typically require non-linear writing processes to integrate part-whole relationships between different functions, languages, and needs (Kern, Willcocks \& van Heck, 2002; Odell et al., 1983; Reither, 1993). The extent to which linear writing processes are used in an organization is dependent on the use of formal writing practices in discourse communities. Founded in the management of technology literature, linear writing practices support over-the-wall work transitions traditionally found in new product development processes (Jelinek, 1979). Jelinek warns, however, that traditional, incremental development processes lead teams to hoping that follow-on organizational members can implement and fix errors and deficiencies in requirements and new products. 
Research on the importance of written communication methods highlights that informal processes may be more important than formal linear processes in the development of contract requirements (Feldman, 1984; O'Reilly, 1989; Rousseau, 1990). Adler (2000) and Dannels (2000) recently found that team-based social perceptions played a much larger role in determining how requirements were developed in team-based designs than linear writing processes. Since writing requirements, especially with some technical content, serve to establish the value of the discourse community developing the requirement(s), an ideal venue to establish value of the outsourcing effort is in team-based designs with colleagues, peers, and potential rivals (Knorr \& Knorr, 1978). The use of linear writing processes works against the integration of discourse communities in the outsourcing of IT work because there is typically not enough time to adequately integrate social considerations and share lessons learned within and between discourse communities. Linear-based writing practices segregate discourse communities relative to time, information sharing, and collective negotiation, all important conditions for developing team-based judgments of value with regard to outsourcing IT work.

Proposition 7: The more team members use linear-based writing processes to develop IT outsource requirements, the less likely team members will form a judgment of value of the IT outsourcing effort.

\section{Emergent Perspective}

\subsection{Awareness of Mediator Role}

Organizations that outsource typically develop requirements based on internal needs and expectations (Beckman \& Mowery, 1993). One traditional role of the outsource team involves the translation of information about customer needs and expectations into numerical contract requirements that eventually become part of the outsource agreement (Adler, 1994; Dannels, 2000). Firms that outsource have to write down what they expect the providing firm to do with regard to goals, performance levels, and consequences if requirements are not met (Davy, 1998; Lacity et al., 1996). However, writing clearly stated requirements is a difficult process given the uncertainty of not knowing what may occur in the future.

Adding cross-functionality (e.g., diverse discourse communities) to outsource teams reduces uncertainty if team members jointly seek new approaches and frameworks effectively (Katzenbach \& Smith, 1993; Salas et al., 1992). Even cross-functional teams, though, cannot reduce all the uncertainty associated with an outsource effort and write IT contract requirements that effectively counter uncertainty. This has led many to question the relevance of IT contract agreements. For instance, MacNeil (1978) contends that contractual agreements, from a post hoc enforcement perspective, are fairly meaningless because of unanticipated future events. Consequently, research indicates that outsource teams need to take on the more emerging perspective of mediation, not translation, placing emphasis on the diversity of team makeup in joint decision making (Dannels, 2000).

While translation involves the ability to assign IT specification language to customer words, the IT mediation role requires a prioritization of contract language, based on multiple customers needs and inputs, into categories or ranges of specification-type language. The mediation role also requires that the outsource team ensure that requirements, from a diverse internal customer perspective, are consistent and relevant before they are written into an organizational contract and made part of an IT outsourcing agreement. For instance, Dobrin (1983) suggests that, from a universalist perspective of language, word usage and grammar can be precisely written to convey meaning to individuals on teams. Consequently, teams that are used in a mediation role to outsource IT infrastructure would be more likely to develop strong beliefs about their role in conveying meaning to diverse discourse communities.

\subsection{Opportunities for Team Members}

Team members who view IT outsourcing work from a broader, emergent perspective will also most likely view the outsourcing effort as an opportunity to advance or acquire new skills (Davy, 1998). This is similar to the positive consequences of turnover where performance increases, conflict is reduced, and morale improves when individuals leave organizations (Staw, 1980). A key strategic advantage in outsourcing IT infrastructure activities is the freeing up of organizational resources for other purposes (Davy, 1998). The outsource effort might be viewed as 

an opportunity for self-expression and individual development, freeing up jobs, or providing more job security (Nicholson, 1996). Davy states that if a firm is outsourcing an IT function that already exists, how a firm approaches the outsourcing effort is key to long-term employee support and morale. Team-based judgments of value are more likely to develop when team members collectively see opportunities for improved organizational efficiency, organizational effectiveness, personal advancement, new skill acquisition, or increased job security.

\subsection{Awareness of the External IT Expertise Role}

A third issue that continues to emerge in firms is the view that IT expertise lies external to the firm due to the rapidity of change, availability of IT consultants, and increasing interconnectivity networks between vendors, providers, and customers. The strategic-theoretic discrepancy model presented by Teng, Cheon, and Grover (1994) offers insight into this perspective from a supply and demand perspective.

On the supply side, it is extremely difficult to find qualified internal personnel with the required technical capabilities and breadth of knowledge to support revenue-generating, strategy-implementing functions. Given the complexity and rapidity with which IT systems change, finding capable resources internal to organizations is difficult. In addition, obtaining the needed equipment in-house, on a real-time basis is becoming more difficult with the diversification of IT systems. Currid (1994) found expectations of increased expertise and shorter implementation periods were common among business executives when outsourcing IT work. Davy (1998) states that IT outsourcing provides firms with opportunities to hand-off work beyond their expertise to firms with experience in those areas. Forbes (1998) suggests that outsourcing decisions be based on hiring firms which have had success with similar assignments. The supply of IT expertise is many times external to a firm because a firm may have a core competency in something other than IT and may decide to unload IT, non-core work in a "contract-out" or "preferred contractor" strategy (Lacity et al., 1996).

From a demand standpoint, corporate functional managers are often unsure what they really need from an IT infrastructure or from an entire IT department (Willcocks, Fitzgerald \& Lacity, 1996). The disconnect between internal users and internal IT providers often leads to technical incompatibilities and IT products and services which fall far short of expectations. Thus, it is not unusual to find that internal users are four times more likely to request outsourcing to outside providers for their IT infrastructure (Teng et al., 1994).

When firms do decide to outsource elements of the IT infrastructure, the traditional viewpoint has held that the expertise lies outside of the organization. In light of recent trends to outsource IT work, this indicates that an organization's management either recognized unavailability of internal IT expertise, the need to develop closer ties with external IT providers, or inefficiencies in past internal IT outsourcing efforts.

IT outsource teams that have experienced unmet expectations and technical incompatibilities with internal IT providers will most likely hold strong beliefs about acquiring expertise that resides external to the organization. A perceived good fit between an IT provider and organizational need fills an organizational gap that enhances the future strategic competitiveness of the firm. Teams that perceive the importance and fit between an outsource provider and organizational need will most likely develop a set of beliefs compatible with supporting the IT outsourcing effort. For instance, outsourcing to Contractor A, a firm with an expertise in installing and maintaining local area networks, can only support a team's beliefs that future organizational communication will be improved. These beliefs will then guide and influence team members as they develop requirements, make decisions, and weigh conditions in outsourcing work to Contractor A. The above discussion leads to the following three propositions:

Proposition 8: Team members who view IT from an emergent perspective will be more likely to form a team-based judgment of value to the extent that any one of the following conditions are met:

Proposition $8_{a}$ : There is agreement between management and the outsource team that outsource team members are viewed as mediators, not translators, in integrating needs and expectations.

Proposition $8_{b}$ : There is agreement between management and the outsource team that the IT infrastructure being outsourced provides new opportunities for internal organizational resources. 
Proposition $8_{c}$ : There is agreement between management and the outsource team that IT expertise resides external to the organization.

\section{Conclusion}

\subsection{The Effects of Team-Based Designs}

Although the concept of outsourcing IT services as a strategic choice has produced some exceptional results, many planners are keeping a watchful eye toward the long-range perspective. Problems such as contract overruns typically fall back to poorly crafted IT contract requirements that do not adequately align the IT infrastructure with revenue-generating functions or business operations (Hirschheim \& Lacity, 1998; Lacity et al., 1996; MacNeil, 1978). In organizations where parts of the IT infrastructure are selectively chosen to be outsourced, the effective management of team-based designs is crucial to follow-on implementation success.

How well outsource requirements are written depends on the how firms are aware of, and manage, the factors and processes presented in Figure 1. We have argued that team-member judgments of value are key to understanding how teams view IT outsourcing efforts. Since team-based designs are fundamentally collaborative (Kleimann, 1993), the more team members are aware of organizational concerns, like the implementation of strategic vision, the more likely team members will be affected by social and political context. For instance, organizational and professional norms can lead to requirements that were not valued by outsourcing teams (Adler, 2000). Recent research and theory indicates that the fundamental problem in outsourcing IT infrastructures are poorly developed contract requirements, an ex ante activity in implementing strategic decisions, that leads to poorly delivered post hoc IT outsourcing products and services (Hirschheim \& Lacity, 1998; Weill \& Broadbent, 1998). Team-based issues complicate strategic implementation issues and contribute to the development of poorly written IT outsource requirements. Underlying the implementation of organizational strategy are the multiple factors affecting team member perceptions of value for the IT outsourcing effort.

\subsection{Suggestions for Future Research}

We propose that explicitly including team-based judgments of value into the IT outsourcing decision represents a more appropriate view of integrating strategy and team-based implementation activities. Many academicians and practitioners need to rethink how team member judgments of value are affected in team-based designs. We argue that without adequate consideration of social context, competing cultural values, and political agendas, the choices made in team settings about outsourcing IT work are uninformed and prone to failure. This may mean that IT requirements developers take on expanded roles. We suggest that the capabilities of IT writers be considered from an organizational, knowledge sharing, and team-based role perspective. IT requirements writers not only need to communicate on a personal level, they must also be aware of social processes that are active on teams and in organizations (Adler, 2000; Bazerman, 1983; Odell \& Goswami, 1985). The inability of IT requirements writers to adequately craft requirements is an important tactical consideration when implementing strategic outsourcing decisions. The ramifications to an organization for not training IT managers in professional writing have never been higher, and, likewise, the benefits have never been greater for organizations that can manage teams and craft appropriate IT outsource requirements.

An empirical investigation of this framework should address the nature of organizational, functional, and team discourse values in relation to the overarching framework developed in our discussion. For instance, how is a team-based design affected by a hierarchy of values (i.e., professional, organizational, and team)? The identification of how values guide cross-functional team members would aid greatly in our understanding of the effects of social interaction (Odell \& Goswami, 1985). Also, are there group agency issues, which differ from classic agency theory in implementing the desires of the principal, especially from a strategy-making-to-implementation perspective?

Team-based designs exacerbate IT outsourcing by making honest, critical discussion and consensus difficult to attain. The ability to adequately manage team-based judgments of value when developing and negotiating IT outsourcing requirements is most likely one of the critical areas organizations need to account for in the future. 
1. Adler, Terry., "The innovation process: Interpreting contract requirements," IEEE Aeronautical Engineering Systems Magazine, Vol. 9, pp. 17-25, 1994.

2. Adler, Terry., "An evaluation of the social perspective in the development of technical requirements," IEEETransactions on Professional Communication, Vol. 43, No. 5, pp. 17-25, 2000.

3. Ang, S. and Cummings, L., "Strategic response to institutional influences on IS outsourcing," Organization Science, Vol. 8, No. 3, pp. 235-256, 1997.

4. Ang, S. and Straub, D., "Production and transaction economies and IS outsourcing: A study of the U.S. banking industry," MIS Quarterly, Vol. 22, No. 4, pp. 535-552, 1998.

5. Anson, C., "Toward a multidimensional model of writing in the academic disciplines," in D.A. Jolliffe (Ed.), Advances in writing research, volume two: Writing in academic disciplines, Ablex Publishing Corp, Norwood, New Jersey, 1988.

6. Bazerman, Charles., "Scientific writing as a social act: A review of the literature of the sociology of science," in P. V. Anderson, R. J. Brockman \& C. R. Miller (Eds.), New essays in technical and scientific communication: Research, theory, practice, Baywood Publishing Co, Farmingdale, New York, 1983.

7. Beckman, S. and Mowery, D., "Getting the right products to market: A study of product definition in the electronics industry," Design Management Journal, pp. 54-61, spring 1993.

8. Bishop, James and Scott, K., "An examination of organizational and team commitment in a self-directed team environment," Journal of Applied Psychology, Vol. 85, No. 3, pp. 439-450, 2000.

9. Bishop, J., Scott, K., and Burroughs, S., "Support, commitment, and employee outcomes in a team environment," Journal of Management, Vol. 26, No. 6, pp. 1113-1132, 2000.

10. Burnham, Christopher, "The consequences of collaboration: Discovering expressive writing in the disciplines," The Writing Instructor, Vol. 6, pp. 17-24, 1986.

11. Cohen, S. and Bailey, D., "What makes teams work: Group effectiveness research from the shop floor to the executive suite," Journal of Management, Vol. 23, No. 3, pp. 239-290, 1997.

12. Colomb, G. and Williams, J., "Perceiving structure in professional prose: A multiply determined experience," in L. Odell \& D. Goswami (Eds.), Writing in nonacademic settings: pp. 87-128, Guilford Press: New York, 1985.

13. Coovert, M., Craiger, J. and Cannon-Bowers, J., "Innovations in modeling and simulating team performance: Implications for decision making," in R. A. Guzzo \& E. Salas (Eds.), Team effectiveness and decision making in organizations: pp. 149-20, Jossey-Bass, San Francisco, 1996.

14. Couture, B. and Rymer, J., "Situational exigence: Composing processes on the job by writer's role and task value," in R. Spilka (Ed.), Writing in the workplace: New research perspectives, Southern Illinois University Press, Carbondale, Illinois, 1993.

15. Currid, C., Computing strategies for reengineering your organization, Prima Publishing, Rocklin, CA, 1994.

16. Dannels, Deborah., "Learning to be professional," Journal of Business and Technical Communication, Vol. 14, No. 1, pp. 5-37, 2000.

17. Davy, J., "Outsourcing human resources headaches," Managing Office Technology, Vol. 43, No. 7, pp. 6-8, 1998.

18. DiRomualdo, A. and Gurbaxani, V., "Strategic intent for IT outsourcing," Sloan Management Review, Vol. 39, No. 4, pp. 67-80, 1998.

19. Dobrin, D., "What's technical about technical writing," in P. Anderson, R. Brockman, \& C. Miller (Eds.), New essays in technical and scientific communication: Research, theory, practice, Baywood Publishing Company, Farmingdale, New York, 1983.

20. Dougherty, D., "Interpretive barriers to successful product innovation in large firms," Organization Science, Vol. 3, No. 2, pp. 179-202, 1992.

21. Duncan, N., "Capturing IT infrastructure flexibility: A study of resource characteristics and their measure," Journal of Management Information Systems, Vol. 12, No. 2, 1995.

22. Dutton, J. and Dukerich, J., "Keeping an eye on the mirror: Image and identity in organizational adaptation," Academy of Management Journal, Vol. 34, No. 3, pp. 517-554, 1991.

23. Earl, M., Management strategies for information technology. London: Prentice-Hall, 1989. 
24. Eisenhardt, K., "Agency theory: An assessment and review," Academy of Management Review, Vol. 14, No. 1, pp. 57-74, 1989.

25. Eisenhardt, K. and Bourgeois, L., "Politics of strategic decision making in high velocity environments: Toward a midrange theory," Academy of Management Journal, Vol. 31: pp. 737-770, 1988.

26. Eisenhardt, K. and Tabrizi, B., "Accelerating adaptive processes: Product innovation in the global computer industry," Administrative Science Quarterly, Vol. 4: pp. 84-110, 1995.

27. Feldman, D., "The development and enforcement of group norms," Academy of Management Review, Vol. 9: pp. 47-53, 1984.

28. Fielden, T., "Keeping your IT partners on a short leash,” InfoWorld, Vol. 23, No. 7, p. $52,2001$.

29. Forbes., "When should you outsource IT functions?" Forbes, Vol. 1, No. 1, pp. 54-55, 1998.

30. Friedlander, F., "Patterns of individual and organizational learning," in S. Srivesta \& Associates (Eds.), The executive mind, Jossey-Bass, San Francisco, California, 1993.

31. Gibson, C., "From knowledge accumulation to accommodation: Cycles of collective cognition in work groups," Journal of Organizational Behavior, Vol. 22, pp. 121-134, 2001.

32. Gordon, J., "Work teams: How far have they come?” Training, Vol. 29, pp. 59-65, 1992.

33. Grover, V., Cheon, M. and Teng, J., "An evaluation of the impact of corporate strategy and the role of information technology on IS functional outsourcing," European Journal of Information Systems, Vol. 3, No. 3, pp. 179-191, 1994.

34. Grover, V. and Ramanlal, P., "Six myths of information and markets: Information technology networks, electronic commerce, and the battle for consumer surplus," MIS Quarterly, Vol. 23, No. 4, pp. 465-495, 1999.

35. Hirschheim, R. and Lacity, M., "Backsourcing: An emerging trend," Journal of Strategic Outsourcing Information, Vol. 45, pp. 78-89, 1998.

36. Hitt, M., Keats, B. and DeMarie, S., "Navigating in the new competitive landscape: Building strategic flexibility and competitive advantage in the $21^{\text {st }}$ century," Academy of Management Executive, Vol. 12, No. 4, pp. 22-42, 1998.

37. Hollenbeck, J., Williams, C., and Klein, H., “An empirical examination of the antecedents of commitment to difficult goals,” Journal of Applied Psychology, Vol. 74, pp. 18-23, 1989.

38. Hopper, M., "Rattling SABRE-New ways to compete in information," Harvard Business Review, Vol. 68 (May-Jun), pp. 118-125, 1990.

39. Jelinek, M., Institutionalizing innovation: A study of organizational learning systems, Praeger Publishers, New York, 1979.

40. Jolliffee, D. and Brier, E., “Studying writers' knowledge in academic disciplines,"In Jolliffe, D. (Ed.), Advances in writing research, volume two: Writing in academic disciplines, Ablex Publishing Corp, Norwood, NJ, 1988.

41. Katzenbach, J. and Smith, D., The Wisdom of Teams, HarperBusiness, New York, 1993.

42. Keil, M., "Escalation of commitment in information systems development: A comparison of three theories," Academy of Management Journal, Best Paper Proceedings: pp. 348-365, 1995.

43. Kern, T., Willcocks, L. and van Heck, E., "The winner's curse in IT outsourcing: To avoid extreme relational trauma," California Management Review, Vol. 44, No. 2, pp. 47-69, 2002.

44. Kleimann, S., "The reciprocal relationship of workplace culture and review," In R. Spilka (Ed.), Writing in the workplace: New research perspectives, Southern Illinois University Press, Carbondale, Illinois, 1993.

45. Knorr, K. and Knorr, D., from scenes to scripts: On the relationship between laboratory research and published paper in science, Research Memorandum No. 132, Vienna Institute for Advanced Studies, 1978.

46. Kramberg-Walker, C., "The need to provide writing support for academic engineers," IEEE Transactions on Professional Communication, Vol. 36, No. 3, pp. 130-136, 1993.

47. Lacity, M. and Hirschheim, R., Beyond the information systems outsourcing bandwagon. John Wiley and Sons Ltd, New York, 1995.

48. Lacity, M. and Willcocks, L., "Interpreting Information Technology Sourcing Decisions From A

49. Transaction Cost Perspective: Findings and Critique," Accounting, Management and Information Technology, Vol. 5, No. 3, pp. 203-244, 1996.

50. Lacity, M. and Willcocks, L., "An empirical investigation of information technology sourcing practices: Lessons from experience,” MIS Quarterly, Vol. 22, No. 3, pp. 363-408, 1998. 
51. Lacity, M., Willcocks, L., and Feeny, D., "The value of selective IT sourcing," Sloan Management Review, Vol. 37, No. 3, pp. 13-20, 1996.

52. Lamir, F., "Contract interpretation," Air Force Contract Law Center Notes, Air Force Material Command, 1992.

53. Latham, G. and Yukl, G., "A review of research on the application of goal setting in organizations," Academy of Management Journal, Vol. 18: pp. 824-845, 1975.

54. Lee, J-N. and Kim, Y-G., "Effect of partnership quality on IS outsourcing: Conceptual framework and empirical validation," Journal of Management Information Systems, Vol. 15, No. 4, pp. 29-52, 1999.

55. Loh, L. and Venkatraman, N., "Dilution of IT sources and the Kodak effect," Information Systems Research, Vol. 3, pp. 334-358, 1992.

56. MacMillan, H., "Managing information systems: Three key Principles for general managers" Journal of General Management, Vol. 22, No. 3, pp. 12-22, 1997.

57. MacNeil, I., "Contracts: Adjustments of long-term economic relations under classical, neoclassical and relational contract law," Northwestern University Law Review, Vol. 72, pp. 854-906, 1978.

58. Magjuka, R. and Baldwin, T., "Team-based employee involvement programs: Effects of design and administration," Personnel Psychology, Vol. 44, pp. 793-812, 1991.

59. Marks, M., Zaccaro, S., and Mathieu, J., "Performance implications of leader briefings and teaminteraction training for team adaptation to novel environments," Journal of_Applied Psychology, Vol. 85, No. 6, pp. 971-986, 2000.

60. Martell, R., Guzzo, R., and Willis, C., "A methodological and substantive note on performance-cue effect in ratings of work group behavior,” Journal of Applied Psychology, Vol. 80, No. 1, pp. 191-195, 1995.

61. Mohammed, S. and Dumville, B., "Team mental models in a team-knowledge framework: Expanding theory and measurement across disciplinary boundaries," Journal of Organizational Behavior, Vol. 22, pp. 89-106, 2001.

62. Nam, K., Rajagopalan, S., Rao, H., and Chaudhury, A., "A two-level investigation of Information Systems Outsourcing," Communications of the ACM, Vol. 39, No. 7, pp. 36-44, 1996.

63. Nicholson, N., "Career systems in crisis: Change and opportunity in the information age," Academy of Management Executive, Vol. 10, No. 4, pp. 40-51, 1996.

64. Niederman, F., Brangeay, J., and Wetherbe, J., "Information systems management issues for the 1990s," MIS Quarterly, Vol. 15, No. 4, pp. 474-500, 1991.

65. Odell, L. and Goswami, D., Writing in nonacademic settings. Guilford Press, New York, 1985.

66. Odell, L., Goswami, D., Herrington, A., and Quick, D., "Studying writing in non-academic settings," In P. Anderson, R. Brockman, \& C. Miller (Eds.), New essays in technical and scientific communication: Research, theory, practice, Baywood Publishing Company, Farmingdale, New York, 1983.

67. Offerman, L., "The science and practice of team development: Improving the link," Academy of Management Journal, Vol. 44, pp. 376-392, 2001.

68. O'Reilly, C., "Corporations, culture \& commitment: Motivation and social control in organizations," California Management Review, Vol. 31, pp. 9-25, 1989.

69. Outsourcing Institute, "The top ten reasons companies outsource," http://www.outsourcing.com//getstart/topten.html, 1996.

70. Plunkett, D., "The creative organization: An empirical investigation of the importance of participation in decision making," Journal of Creative Behavior, Vol. 24, pp. 140-148, 1990.

71. Reither, J., "Bridging the gap: Scenic motives for collaborative writing in workplace and school," in R. Spilka (Ed.), Writing in the workplace: New research perspectives, pp. 195-206, Southern Illinois University Press, Carbondale, Illinois, 1993.

72. Remenyi, D., "Ten common information systems mistakes," Journal of General Management, Vol. 21 , No. 4, pp. 78-89, 1996.

73. Rentsch, J. and Klimoski, R., "Why do 'great minds' think alike? Antecedents of team member schema agreement," Journal of Organizational Behavior, Vol. 22, pp. 107-120, 2001.

74. Renze, J., "Important factors in the technical proposal process according to engineering faculty," IEEE Transactions on Professional Communication, Vol. 39, No. 2, pp. 87-98, 1996.

75. Richmond, W., and Seidmann, A., "Software development outsourcing contract: Structure and business value,” Journal of Management Information Systems, Vol. 10, No. 1, pp. 57-72, 1993. 
76. $\quad$ Rokeach, M., The Nature of Human Values. Free Press, New York, 1973.

77. Rousseau, D., “Assessing organizational culture: The case for multiple methods," in B. Schneider (Ed.), Organizational climate and culture: pp. 153-192, Jossey-Bass, San Francisco, 1990.

78. Salas, E., Dickinson, T., Converse, S. and Tannenbaum, S., "Toward an understanding of team performance and training," in R. W. Swezey \& Salas (Eds.), Teams: Their training and performance, pp. 3-29, ABLEX Press, Norwood, New Jersey, 1992.

79. Sashkin, M., "Participative management is an ethical imperative," Organizational Dynamics, Spring: pp. 422, 1984.

79. Scarbrough, H., "Blackboxes, hostages and prisoners,” Organization Studies, Vol. 16, No. 6, pp. 991-998, 1995.

80. Schein, E., "The role of the founder in creating organizational culture," Organizational Dynamics, Summer: pp. 13-28, 1983.

81. Selzer, J., "What constitutes a "readable" technical style," in P. Anderson, R. Brockman, and C. Miller (Eds.), New essays in technical and scientific communication: Research, theory, practice, Baywood Publishing Company, Farmingdale, New York 1983.

82. Senge, P., The Fifth Discipline. Doubleday Currency, New York, 1990.

83. Sengupta, K. and Zviran, M., "Measuring user satisfaction in an outsourcing environment," IEEE Transactions on Engineering Management, Vol. 44, No. 4, pp. 414-421, 1997.

84. Skinner, J. and Bond, B., "The outsourcing decision: Opting for value," Australian Accountant, Vol. 67, No. 10, pp. 42-44, 1997.

85. Starbuck, W. and Milliken, F., "Challenger: Fine-tuning the odds until something breaks," Journal of Management Studies, Vol. 25, pp. 319-341, 1988.

86. Staw, B., "The consequences of turnover. Journal of Occupational Behavior, Vol. 12, pp. 253-270, 1980.

87. Staw, B. and Fox, F., "Escalation: The determinants of commitment to a chosen course of action," Human Relations, Vol. 30, pp. 431-450, 1997.

88. Teng J., Cheon, M., and Grover, V., "Decisions to outsource information systems functions: Testing a strategy theoretic discrepancy model," Decision Sciences, Vol. 26, No. 1, pp. 75-103, 1994.

89. Trice, A., Occupational subcultures in the workplace, ILR Press, Cornell University, Ithaca, New York, 1993.

90. Tyerman, A. and Spencer, C., “A critical text of the sheriff's robber's cave experiments: Intergroup competition and cooperation between groups of well-acquainted individuals," Small Group Behavior, Vol. 14, pp. 515-531, 1983.

91. Venkatraman, N., "Beyond outsourcing: Managing IT resources as a value center. Sloan Management Review," Vol. 38, No. 3, pp. 51-64, 1997.

92. Wegner, D. “Transactive memory: A contemporary analysis of group mind,” pp. 185-208 in G. Mullen \& G. Goethals (Eds.), Theories of Group Behavior, Springer-Verlag, New York, 1986.

93. Weick, Karl \& Roberts, K., "Collective mind in organizations: Heedful interrelating on flight decks," Administrative Science Quarterly, Vol. 3, pp. 357-381, 1993.

94. Weill, Peter and Broadbent, M., Leveraging the new infrastructure: How market leaders capitalize on information technology. Harvard Business School Press, Boston, 1998.

95. Westley, F. and Mintzberg, H., "Visionary leadership and strategic management. Strategic Management Journal," Vol. 10, pp. 17-33, 1998.

96. Wheelwright, Stephen and Clark, Kim., Revolutionizing product development: quantum leaps in speed, efficiency, and quality. The Free Press, New York, 1992.

97. Willcocks, L., Fitzgerald, G. and Lacity, Mary., "To outsource IT or not? Recent research on economics and evaluation practice," European Journal of Information Systems, Vol. 5, No. 3, pp. 143-160, 1996.

98. Williamson, Oliver, Markets and hierarchies: Analysis and antitrust implications, The Free Press, New York, 1983.

99. Woolridge, B. and Floyd, S., "Strategic process effects on consensus. Strategic Management Journal," Vol. 10, pp. 295-302, 1990.

100. Zand, D., "Trust and managerial problem solving," Administrative Science Quarterly, Vol. 17, pp. 229-239, 1972. 